\title{
HUBUNGAN DUKUNGAN SOSIAL KELUARGA DENGAN TINGKAT KEMANDIRIAN LANSIA DI DESA TAAL TAPEN KABUPATEN BONDOWOSO
}

\author{
Ratu Narendra Duhita ${ }^{1}$, Arif Eko Trilianto ${ }^{2}$, Pasidi Shidiq ${ }^{3}$ \\ 1. Universitas Nurul Jadid Paiton Probolinggo, \\ Email: adhehartini@gmail.com \\ 2. Dinas Kesehatan Probolinggo \\ 3. Dinas Kesehatan Bondowoso
}

\section{Abstract}

Elderly is an advanced stage of a life process that will be experienced by all individuals. The aging process in the elderly tends to potentially reduce the level of independence of the elderly in carrying out daily activities. This type of research is a correlational analytic method that aims to reveal the relationship of Family Social Support with the Level of Independence of the Elderly in Taal Village RT 14, RW 04 Tapen Bondowoso Regency. correlative between variables. Data were obtained about the category of family social support with the independence of the elderly in the village of RT 14, RW 04 Tapen Bondowoso district most respondents in the category of social support with good elderly independence were 15 people (93.3\%), while a small proportion of social support categories with poor elderly independence were not good as many as 2 people (10.0\%). The results of the analysis of the relationship of social support with the level of independence of the elderly Spearman rho statistical test results with the help of SPSS for Windows software program, obtained the value of $p=0,000$ with a significant level of $0.05(p<0.05)$ so that it can be concluded that $\mathrm{HO}$ is rejected which means there the relationship of family social support with the independence of the elderly. If the family's social support is good, it will affect the level of independence of the elderly and among them, the cause of the elderly's independence is due to the lack of family social support and decreased the function of all cells in the elderly.

Keywords: Family Social Support, Elderly Level of Independence. 


\section{Abstrak}

Lansia merupakan tahap lanjut dari suatu proses kehidupan yang akan di alami oleh semua individu. Proses penuaan pada lansia cenderung berpotensi terhadap penurunan tingkat kemandirian lansia dalam melakukan aktivitas sehari-hari. Jenis penelitian yang digunakan adalah metode analitik korelasional yang bertujuan mengungkapkan hubungan Hubungan Dukungan Sosial Keluarga Dengan Tingkat Kemandirian Lansia Di Desa Taal Rt 14/ Rw 04 Tapen Kabupaten Bondowoso. korelatif antar variable. Di dapatkan data tentang kategori dukungan sosial keluarga dengan kemandirian lansia di desa taal rt. 14 / rw.04 kecamatan tapen kabupaten bondowoso sebagian besar responden kategori dukungan sosial dengan kemandirian lansia baik sebanyak 15 orang (93.3\%), sedangkan sebagian kecil kategori dukungan sosial dengan kemandirian lansia tidak baik sebanyak 2 orang (10.0\%). Hasil analisi hubungan dukungan sosial dengan tingkat kemandirian lansia hasil uji statistik spearman rho dengan bantuan software program SPSS for windows, didapatkan hasil nilai $\mathrm{p}=0.000$ dengan tingkat signifikan 0,05 ( $p<0,05$ ) sehingga dapat disimpukan bahwa HO ditolak yang artinya ada hubungan dukungan sosial keluarga dengan tingkat kemandirian lansia. Jika dukungan sosial keluarga baik maka akan mempengaruhi tingkat kemandirian lansia dan diantaranya penyebab ketidakmandirian lansia disebabkan oleh karena kurangnya dukungan sosial keluarga serta penurunan fungsi semua sel pada lansia.

Kata kunci: Dukungan Sosial Keluarga, Tingkat Kemandirian Lansia 


\section{PENDAHULUAN}

Lanjut Usia adalah seseorang yang telah memasuki usia 60 tahun ke atas. Lansia merupakan tahap lanjut dari suatu proses kehidupan yang akan di alami oleh semua individu. Lansia mengalami proses penuaan. Proses penuaan pada lansia cenderung berpotensi terhadap penurunan tingkat kemandirian lansia dalam melakukan aktivitas sehari-hari (Azizah., 2011).

Tingkat kemandirian adalah kebebasan untuk bertindak, tidak tergantung pada orang lain,tidak terpengaruh pada orang lain dan bebas mengatur diri sendiri atau aktivitas seseorang baik individu maupun kelompok dari berbagai kesehatan atau penyakit. Penurunan tingkat kemandirian dapat mengakibatkan kecemasan pada lansia.Dari hasil survei di masyarakat masih jumpai banyak lansia yang mengalami penurunan tingkat kemandirian dan mengalami kecemasan (Amelia Meta dkk,2011).

$$
\text { Indikator pada Lansia, }
$$

Berdasarkan data dari indikator ekonomi ,dengan adanya penurunan kemampuan fisik maka normalnya akan terjadi gangguan kemampuan mobilisasi pada lansia, hal ini akan menyebabkan terganggunya proses ekonomi pada orang usia lanjut, karena itu pada bab sebelumnya telah di sajikan data Rasio ketergantungan lansia,yang membuktikan beban ekonomi yang harus ditanggung oleh penduduk usia produktif untuk membiayai lansia dengan asumsi bahwa lansia tersebut secara ekonomi bukanlah lansia yang produktif. Selain itu, angka tersebut mencerminkan pula ketersediaan tenaga kerja produktif. Semakin tinggi angka ketergantungan lansia semakin langka tenaga kerja produktif. Menurut UU No. 13 tahun 1998 Pasal 1 Ayat 2 tentang Kesejahteraan Lanjut Usia menyatakan bahwa lanjut usia adalah seseorang yang telah mencapai usia 60 tahun ke atas (Undang-Undang Republik Indonesia Nomor 13 Tahun 1998 Tentang Kesejahteraan Lanjut Usia).

Pada tahun 2010 jumlah lansia di Indonesia 23.992.553 jiwa (9,77\%), sedangkan jumlah lansia di Jawa Timur pada tahun 2.971.004 jiwa (Badan Pusat Statistik Indonesia). Menurut WHO-Comunity Studyof the Elderly, Central Java, di Indonesia masalah kesehatan. Menurut WHO, Khususnya di kawasan Asia Tenggara populasi Lansia sebesar $8 \%$ atau sekitar 142 juta jiwa. Pada tahun 2050 diperkirakan populasi Lansia meningkat 3 kali lipat dari tahun ini. Pada tahun 2000 jumlah Lansia sekitar 5,300,000 (7,4\%) dari total polulasi, sedangkan pada tahun 2010 jumlah Lansia 24,000,000 (9,77\%) dari total populasi, dan tahun 2020 diperkirakan jumlah Lansia mencapai $28,800,000 \quad(11,34 \%)$ dari total populasi. Sedangkan di Indonesia sendiri pada tahun 2020 diperkirakan jumlah Lansia sekitar 80.000.000. Kabupaten / Kota Bondowoso Tahun 2019 Yaitu : Maesan Jumlah : 6.845 Persentase 67,93\%, Grujugan Jumlah : 5.535 Persentase 55,77\%, Tamanan Jumlah : 5.321 Persentase 54,60\%, Jambesari Jumlah : 5.239 Persentase 46,83\%, Pujer Jumlah : 5.122 Persentase 45,13\%, Tlogosari Jumlah : 5.078 Persentase 43,53 \%, Sukosari Jumlah : 4.243 Persentase 42,40\%, Sumber Wringin Jumlah : 3.990 Persentase 30,90\%, Tapen Jumlah : 3.950 Persentase 30,69\% (Kecamatan 
Dalam Angka. Prevalensi Jumlah Penduduk Lansia Kabupaten Bondowoso).

Berdasarkan dari hasil studi pendahuluan di Kota Bondowoso Tapen No 9 dan Mayoritas penduduknya Lansia tepatnya di Desa Tapen. Dan yang di lakukan oleh peneliti Tepatnya di Desa Taal RT 14, RW 02 Kecamatan Tapen Kabupaten Bondowoso, di dapatkan dari 10 lansia, dan di dapatkan hasil lansia yang mampu memenuhi aktivitasnya secara mandiri sebanyak 4 (40\%) lansia, dan lansia yang aktivitasnya sebagian di bantu orang lain sebanyak 2 (20\%) lansia, dan lansia yang tidak mampu memenuhi aktivitasnya sebanyak 4 (40\%) lansia hal ini disebabkan karena banyak sekali lansia yang mengalami gangguan dalam aktivitasnya dikarenakan sudah banyak mengalami penurunan semua fungsi sel tubuh dan juga banyak lansia yang tidak mampu memenuhi kebutuhannya.

Riset terdahulu tentang kemandirian dalam meningkatnya usia harapan hidup penduduk dapat menyebabkan peningkatan jumlah lansia dari tahun ketahun. Peningkatan jumlah lansia akan menyebabkan berbagai masalah kesehatan seperti meningkatnya penyakit degeneratif dan kanker yang menyebabkan penurunan produktifitas lansia. Penurunan produktifitas pada lansia terjadi karena penurunan fungsi, sehingga dapat menyebabkan lansia mengalami penurunan kemandirian dalam melaksanakan kegiatan harian. Adapun tujuan dari penelitian ini adalah mengidentifikasi gambaran tingkat kemandirian dalam memenuhi activities daily living (Mustika Irma Sari, 2009).

Tingkat kemandirian pada lansia dapat di lihat dari kemampuan lansia dalam melakukan aktivitas sehari - hari, seperti mandi, berpakaian rapi, pergi ke toilet,berpindah tempat, dapat mengontrol BAK, atau BAB, serta dapat makan sendiri. Penurunan tingkat kemandirian pada lansia seringkali menimbulkan kecemasan. Kecemasan adalah keadaan ketika individu/kelompok mengalami perasaan gelisah (penilaian atau opini) dan aktivasi saraf otonom dalam berespon terhadap ancaman yang tidak jelas, nonspesifik (Jumita Rina, Dkk, 2012).

Lanjut usia merupakan bagian dari proses kehidupan yang tidak dapat dihindari dan akan dialami oleh setiap manusia. Pada tahap ini manusia mengalami banyak perubahan baik secara fisik maupun mental, dimana terjadi kemunduran dalam berbagai fungsi dan kemampuan yang pernah dimilikinya.Lanjut Usia adalah seseorang yang telah mencapai usia 60 tahun ke atas. Sebagai dampak keberhasilan pembangunan kesehatan di Indonesia salah satunya adalah meningkatnya angka harapan hidup di Indonesia sehingga populasi lansia juga meningkat. Berdasarkan data Biro Pusat Statistik tahun 2014, umur Harapan Hidup (UHH) di Indonesia untuk wanita adalah 73 tahun dan untuk pria adalah 69 tahun. Menurut Bureau of the Cencus USA (1993), Indonesia pada tahun 1990-2025 akan mempunyai kenaikan jumlah lanjut usia sebesar 414\%.

Pasien lanjut usia mempunyai ciri-ciri : memiliki beberapa penyakit 
kronis/menahun, gejala penyakitnya tidak khas, fungsi organ yang menurun, tingkat kemandirian berkurang, sering disertai masalah nutrisi, karena alasan tersebut perawatan pasien geriatri berbeda dengan pasien yang lain.

Masalah-masalah kesehatan yang sering terjadi pada lansia berbeda dari orang dewasa, yang sering disebut dengan sindroma geriatri yaitu kumpulan gejala-gejala mengenai kesehatan yang sering dikeluhkan oleh para lanjut usia dan atau keluarganya yaitu : Immobility (kurang bergerak), Instability (mudah jatuh), Incontinence (beser BAB/BAK), Intellectual impairment (gangguan intelektual/ demensia), Infection (infeksi), Impairement of hearing, vision and smell (gangguan pendengaran, penglihatan dan penciuman), Isolation (Depression), Inanition (malnutrisi), Impecunity (kemiskinan), Iatrogenic (menderita penyakit pengaruh obat-obatan), Insomni a(sulit tidur), Immunodefficiency (penurunan sistem kekebalan tubuh), Impotence (Gangguan seksual), Impaction (sulit buang air besar)

Riset terdahulu dukungan sosial pada lanjut usia merupakan fase kehidupan yang umumnya akan dilalui oleh setiap manusia. Fase ini merupakan proses dari berkurang dan hilangnya beberapa sumber primer yang mendukung kehidupan lansia, baik sumebr biologis, ekonomi, soaial dan ekonomi. Panti Lansia (wreda atau jompo) disediakn dengan tujuan utama adalah menopang atau mendukung kehidupan lansia. Tidak sedikit para lanjut usia yang tinggal di Panti masih memiliki keluarga, baik keluarga keluarga inti atau keluarga besar (Amelia Meta dkk, 2011).

Berdasarkan fenomena diatas, peneliti sebagai tenaga kesehatan merasa tertarik untuk melakukan penelitian dengan judul "Hubungan dukungan sosial dengan tingkat kemandirian lansia di Desa Taal Kecamatan Tapen Kabupaten Bondowoso".

\section{METODE PENELITIAN}

Penelitian ini menggunakan rancangan penelitian kuantitatif dengan pendekatan Cross-Sectional. Populasi dalam penelitian ini diperkirakan populasi pada penelitian ini adalah 285, dengan jumlah sampel sebanyak 166 responden. Tehnik pengambilan sampel dilakukan secara accidental sampling. Penelitian dilakukan di Desa Taal RT 14, RW 04 Kecamatan Tapen Kabupaten Bondowoso pada bulan April sampai dengan Mei 2019. Instrument dalam penelitian ini adalah kuesioner dengan skala likert. Analisa data dilakukan secara univariat dan bivariat dengan uji Spearmen Rho, dengan signifikansi $\mathrm{p}=0,05$. Pada penelitian ini apabila angka probabilitas lebih kecil dari 0,5 maka HO di tolak yang berarti ada hubungan dukungan sosial dengan kemandirian lansia, sebaliknya jika lebih besar dari atau sama dengan 0,5 maka HO di terima yang berarti tidak ada hubungan dukungan sosial dengan kemandirian lansia

\section{HASIL PENELITIAN \\ Data umum :}

1. Karakteristik

Responden Berdasarkan Jenis Kelamin.

Tabel 1 Distribusi Responden Berdasarkan jenis kelamin

\begin{tabular}{ccc}
$\begin{array}{c}\text { Jenis } \\
\text { kelamin }\end{array}$ & $\begin{array}{c}\text { Frekuensi } \\
(\mathrm{f})\end{array}$ & $\begin{array}{c}\text { Presentase } \\
(\%)\end{array}$ \\
\hline
\end{tabular}




\begin{tabular}{ccl} 
Laki-laki & 82 & 49.4 \\
Perempuan & 84 & 50.6 \\
\hline Total & 166 & 100 \\
\hline Sumber & $:$ Data Primer & Kuesioner \\
& Penelitian 2019
\end{tabular}

Berdasarkan Tabel 1

didapatkan bahwa setengahnya adalah berjenis kelamin perempuan sebanyak 84 responden.

2. Karakteristik responden berdasarkan usia.

Tabel 2 Distribusi Responden Berdasarkan usia

\begin{tabular}{ccc}
\hline Usia & $\begin{array}{c}\text { Frekuensi } \\
(\mathrm{f})\end{array}$ & $\begin{array}{c}\text { Presentase } \\
(\%)\end{array}$ \\
\hline $\begin{array}{c}60-66 \\
\text { Tahun }\end{array}$ & 70 & 42.2 \\
$67-68$ & 14 & 8.4 \\
Tahun & & 49.4 \\
$\begin{array}{c}69-74 \\
\text { Tahun }\end{array}$ & 82 & 100 \\
\hline Total & 166 & Kuesioner \\
\hline Sumber & $:$ Data Primer & Penelitian 2019
\end{tabular}

Berdasarkan Tabel 2 didapatkan bahwa hampir setengahnya responden berusia 69 - 74 Tahun sebanyak 82 responden.

3. Karakteristik Berdasarkan Pekerjaan

Tabel 3 Distribusi Responden Berdasarkan Pekerjaan

\begin{tabular}{ccc}
\hline Pekerjaan & $\begin{array}{c}\text { Frekuensi } \\
(\mathrm{f})\end{array}$ & $\begin{array}{c}\text { Presentase } \\
(\%)\end{array}$ \\
\hline IRT & 53 & 31.9 \\
Tani & 87 & 52.4 \\
Wiraswasta & 26 & 15.7 \\
\hline Total & 166 & 100.0 \\
\hline Sumber & $:$ Data Primer & Kuesioner \\
& Penelitian 2019
\end{tabular}

Berdasarkan Tabel 3 diatas didapatkan bahwa hampir sebagian besar responden bekerja sebagai Tani yaitu sebanyak 87 responden

4. Karakteristik responden berdasarkan pendidikan
Tabel 4 Distribusi Responden Berdasarkan pendidikan

\begin{tabular}{ccc}
\hline Pendidikan & $\begin{array}{c}\text { Frekuensi } \\
\text { (f) }\end{array}$ & $\begin{array}{c}\text { Presentase } \\
(\%)\end{array}$ \\
\hline $\begin{array}{c}\text { SD atau } \\
\text { sederajat }\end{array}$ & 90 & 54.2 \\
$\begin{array}{c}\text { SMP atau } \\
\text { sederajat }\end{array}$ & 65 & 39.2 \\
$\begin{array}{c}\text { SMA atau } \\
\text { sederajat }\end{array}$ & 11 & 6.6 \\
\hline Total & 166 & 100 \\
\hline Sumber : Data Primer & Kuesioner \\
& $\begin{array}{c}\text { Penelitian 2019 } \\
\text { But }\end{array}$
\end{tabular}

Berdasarkan Tabel 4 didapatkan bahwa hampir sebagian besar pendidikan responden adalah Sekolah Dasar atau sederajat sebanyak 90 responden.

\section{Data Khusus :}

1. Dukungan Sosial Keluarga

Tabel 5 Distribusi Responden Berdasarkan Dukungan sosial

\begin{tabular}{ccc}
\hline $\begin{array}{c}\text { Dukungan } \\
\text { Sosial }\end{array}$ & $\begin{array}{c}\text { Frekuensi } \\
\text { (f) }\end{array}$ & $\begin{array}{c}\text { Presentase } \\
(\%)\end{array}$ \\
\hline Tidak Baik & 26 & 15.7 \\
Cukup & 44 & 26.5 \\
Baik & 96 & 57.8 \\
\hline Total & 166 & 100.0
\end{tabular}

Sumber : Data Primer Kuesioner Penelitian 2019

Pada Tabel 5 diatas menunjukkan bahwa sebagian kecil memiliki dukungan sosial keluarga tidak baik yaitu sebanyak 26 responden, hampir setengahnya cukup sebanyak 44 responden dan hampir sebagian besar memiliki dukungan sosial keluarga baik sebanyak 96 responden.

2. Kemandirian lansia

Tabel 6 Distribusi frekuensi responden penelitian menurut kemandirian lansia

\begin{tabular}{ccc}
\hline $\begin{array}{c}\text { Tingkat } \\
\text { kesehatan } \\
\text { lansia }\end{array}$ & $\begin{array}{c}\text { Frekuensi } \\
(\mathrm{f})\end{array}$ & $\begin{array}{c}\text { Persentase } \\
(\%)\end{array}$ \\
\hline $\begin{array}{c}\text { Dibantu Total } \\
\text { Sebagian }\end{array}$ & 30 & 18.1 \\
\hline
\end{tabular}




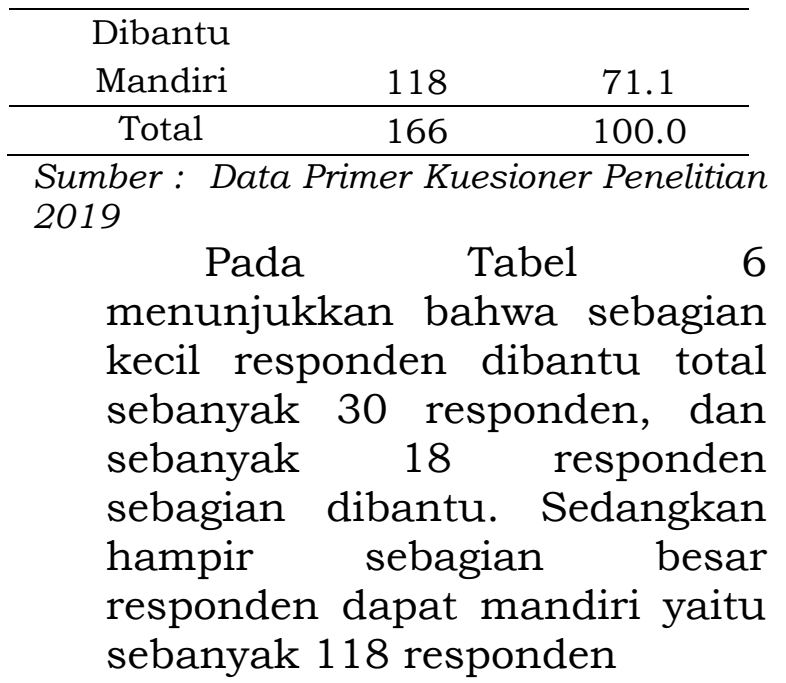

3. Distribusi Frekuensi Dukungan Sosial Keluarga dengan Kemandirian Lansia.

Tabel 7 Distribusi Frekuensi Dukungan Sosial Keluarga dengan Kemandirian Lansia

\begin{tabular}{|c|c|c|c|c|c|c|c|c|c|}
\hline & & \multicolumn{6}{|c|}{ Kemandirian Pada Lansia } & \multirow{2}{*}{\multicolumn{2}{|c|}{ Total }} \\
\hline & & \multicolumn{2}{|c|}{ Dibantu Total } & \multicolumn{2}{|c|}{ Sebagian Dibantu } & \multicolumn{2}{|c|}{ Mandiri } & & \\
\hline & & $\mathrm{F}$ & $\%$ & $\mathrm{~F}$ & $\%$ & $\mathrm{~F}$ & $\%$ & $\mathrm{~F}$ & $\%$ \\
\hline \multirow{3}{*}{$\begin{array}{c}\text { Dukungan Sosi } \\
\text { Keluarga }\end{array}$} & Tidak Baik & 26 & $15,7 \%$ & 0 & $0,0 \%$ & 0 & $0,0 \%$ & 26 & $15,7 \%$ \\
\hline & Cukup & 4 & $2,4 \%$ & 1 & $0,6 \%$ & 39 & $23,5 \%$ & 44 & $26,5 \%$ \\
\hline & Baik & 0 & $0,0 \%$ & 17 & $10,2 \%$ & 79 & $47,6 \%$ & 96 & $57,8 \%$ \\
\hline \multicolumn{2}{|c|}{ Total } & 30 & $18,1 \%$ & 18 & $10,8 \%$ & 118 & $71,1 \%$ & 166 & $100 \%$ \\
\hline \multicolumn{3}{|c|}{ P Value 0,000} & \multicolumn{5}{|c|}{ Correlation Coefficient 0,529 } & & \\
\hline
\end{tabular}

Sumber : Data Primer Kuesioner Penelitian 2019

Dari hasil SPSS (Statistikal Package for the Social Sciens) uji statistik Spearman's Rho dengan derajat kemaknaan $p \leq$ 0,05 . Didapatkan $p$ value 0,000 yang berarti Ho ditolak dan $\mathrm{H} 1$ diterima maka, hubungan dukungan sosial dengan kemandirian lansia. dengan tingkat Correlation Coefficient 0,529 .

\section{PEMBAHASAN}

\section{Dukungan Sosial}

Dari Hasil Penelitian Pada tabel 5.5 di Dapatkan Tata Tentang Kategori Dukungan Sosial Responden di Tesa Taal RT 14, RW 02 Kecamatan Tapen Kabupaten Bondowoso bahwa sebagian kecil memiliki dukungan sosial keluarga tidak baik yaitu sebanyak 26 responden, hampir setengahnya cukup sebanyak 44 responden dan hampir sebagian besar memiliki dukungan sosial keluarga baik sebanyak 96 responden. Dukungan Sosial yaitu mengacu pada kenyamanan, perhatian, penghargaan, atau bantuan yang diberikan Orang Lain atau Kelompok Kepada individu. Sementara Dukungan Sosial yang Didefinisikan Oleh Lahey (2007) Sebagai Peran yang Dimainkan oleh Teman-teman yang Relatif dalam Memberikan Nasihat, Bantuan dan Beberapa diantaranya Untuk menceritakan perasaan pribadi. Menurut Johnson Dukungan Sosial Merupakan Keberadaan Orang Lain yang Dapat Diandalkan untuk Memberi Bantuan, Semangat, Penerimaan dan Perhatian, Sehinga bisa Meningkatkan Kesejahteraan Hidup Bagi individu yang Bersangkutan (Amelia Meta dkk,2011).

Dukungan sosial dikategorikan baik, cukup, tidak baik. Sebagian besar dukungan sosial pada lansia adalah cukup. Hal ini dikarenakan peran keluarga menerapkan dukungan sosial yang baik. Dapat dikatakan dukungan sosial baik jika keluarga dapat memberikan perhatian yang baik bagi lansia tersebut meskipun sebagian besar berpendidikan dasar tetapi faktor dukungan dari keluarga dari setiap individu dari lansia tersebut sangatlah tinggi sehingga dapat membuat para 
lansia di desa taal RT 14, RW 02 kecamatan tapen kabupaten bondowoso mempunyai dukungan sosial keluarga yang baik, sehingga hal tersebut perlu di pertahankan dan di tingkatkan sehingga dukungan sosial yang cukup baik tersebut meningkat menjadi dukungan sosial yang baik nantinya.

Salah satu fungsi keluarga adalah fungsi asih dimana antar anggota keluarga saling memberikan kasih sayang dan rasa aman, memberikan perhatian dan kehangatan terutama pada lansia yang mengalami penurunan kemampuan fisik. Dalam teori kepribadian menurut Ericson (1902-1994) menyatakan lansia (yang usianya diatas 60 tahun) merasa hidup mereka sudah dekat dengan akhir hayat dan pada masa ini kasih sayang dari lingkup keluarga terdekat merupakan kenikmatan tersendiri. Hal ini menunjukkan bahwa perawatan oleh keluarga akan menguntungkan tidak hanya secara fisik tapi juga psikologis lansia.

\section{Kemandirian Lansia}

Sebagian besar responden kategori kemandirian lansia yang mandiri menunjukkan bahwa sebagian kecil responden dibantu total sebanyak 30 responden, dan sebanyak 18 responden sebagian dibantu. Sedangkan hampir sebagian besar responden dapat mandiri yaitu sebanyak 118 responden.

Berdasarkan hasil penelitian diketahui bahwa sebagian besar lansia bahwa sebanyak $61,4 \%$ lansia mampu melaukan aktivitas pemenuhan kebutuhan hidup dasar secara mandiri seperti mandi, makan, eliminasi dan melaksanakan penemuhan kebutuhan rohani khususnya dalam beribadah secara mandiri. Akan tetapi terhadap $53,4 \%$ lansia mengalami kesulitan dalam melakukan aktivitas menyuci baju. Penurunan kemampuan aktivitas sehari-hari seiring dengan bertambahnya umur dan tidak ada perbedaan kemandirian aktivitas seharihari pada lansia laki-laki dan wanita. Masalah aktivitas sehari-hari yang dialami lansia akan semakin meningkat seiring bertambahnya usia dan khususnya pada orang yang berumur diatas 85 tahun, sedangkan menurut jenis kelamin tidak memberi pengaruh yang nyata Mempertahankan

kemandirian pada lansia umumnya sudah mandiri, kemandirian ini sangat penting untuk merawat dirinya dalam memenuhi kebutuhan dasar manusia. Meskipun sulit untuk anggota keluarga yang lebih muda untuk menerima orang tua melakukan aktivitas seharihari secara lengkap dan lambat, dengan pemikiran dan cara sendiri. Lansia diakui sebagai individu yang mempunyai karakteristik yang unik, oleh sebab itu perawat dan keluarga membutuhkan pengetahuan untuk memenuhi kemampuan lansia untuk berpikir, berpendapat dan mengambil keputusan untuk meningkatkan kesehatan. 
Hal tersebut signifikan terhadap teori-teori diatas bahwa kemandirian lansia dipengaruhi oleh dukungan sosial yang baik dari keluarganya. Dari hasil yang di dapatkan, peneliti berpendapat bahwa dukungan sosial keluarga yang baik dapat membuat lansia mandiri dalam hal kemandiriannya. Walaupun pada kenyataannya keluarga di desa Taal Kecamatan Tapen Kabupaten Bondowoso berpendidikan dasar, dan pekerjaan tani tetapi pada kenyataannya keluarga mampu memberikan dukungan sosial yang cukup baik bagi lansia tersebut dan memperoleh keadaan mandiri.

3. Hubungan Dukungan Sosial Dengan Kemandirian Lansia Di Desa Taal Kecamatan Tapen Kabupaten Bondowoso.

Dari hasil SPSS (Statistikal Package for the Social Sciens) uji statistik Spearman's Rho dengan derajat kemaknaan $\mathrm{p} \leq$ 0,05 . Didapatkan $\mathrm{p}$ value 0,000 yang berarti Ho ditolak dan $\mathrm{H} 1$ diterima maka, hubungan dukungan sosial dengan kemandirian lansia. dengan tingkat Correlation Coefficient 0,529 .

Dukungan

sosial merupakan keberadaan orang lain yang dapat diandalkan untuk memberi bantuan, semangat, penerimaan dan perhatian, sehingga bisa meningkatkan kesejahteraan hidup bagi individu yang bersangkutan.

Dukungan sosial akan mempengaruhi individu tergantung pada atau ada tidaknya tekanan dalam kehidupan individu. Tekanan tersebut dapat berasal dari individu itu sendiri atau dari luar dirinya untuk menghindari gangguan baik secara fisik dan psikologis. Individu membutuhkan orang lain disekitarnya untuk memberi dukungan guna memperoleh kenyamanannya.

Keluarga mempunyai peran penting dalam menunjang kemandirian usia lanjut. Karena keluarga memiliki kedekatan dan keterikatan baik fisik maupun emosional. Ketidakmandirian lansia disebabkan tiga hal yaitu keterbatasan fisik dan atau mental, memilih untuk dibantu dalam satu aktivitas tertentu namun mandiri dalam aktivitas lainnya, serta tidak adanya dukungan keluarga. Dengan demikian dukungan keluarga sangat berhubungan dalam mendukung kemandirian lansia untuk menjaga kesehatan fisik maupun kejiwaannya. Sehingga meningkatkan kesehatan dan kualitas hidup lansia. Para lansia akan dapat menikmati hari tua mereka dengan tentram dan damai yang pada akhirnya akan memberikan banyak manfaat bagi semua anggota keluarga yang lain

\section{PENUTUP \\ Kesimpulan}

Dari hasil penelitian dan pembahasan penelitian di atas dapat di simpulkan sebagai berikut:

a. Dukungan Sosial keluarga responden penelitian di desa Taal RT 14, RW 04 
Kecamatan Tapen Kabupaten Bondowoso adalah sebagian besar memiliki dukungan sosial keluarga baik sebanyak 96 responden.

b. Tingkat Kemandirian lansia di desa Taal RT 14, RW 04 Kecamatan Tapen Kabupaten Bondowoso hampir sebagian besar responden mandiri yaitu sebanyak 118 responden

c. uji statistik Spearman's Rho dengan derajat kemaknaan $\mathrm{p}$ $\leq 0,05$. Didapatkan $\mathrm{p}$ value 0,000 yang berarti Ho ditolak dan H1 diterima maka, hubungan dukungan sosial dengan kemandirian lansia. dengan tingkat Correlation Coefficient 0,529

\section{DAFTAR PUSTAKA}

$\begin{array}{ccc}\text { Ali, } & \text { Z. } 2009 & \text { Pengantar } \\ \text { Keperawatan } & \text { Keluarga. } \\ \text { Jakarta : EGC. } & \end{array}$

Amelia Meta dkk,2011, 'Hubungan dukungan sosial dengan depresi pada lansia yang tinggal Di Panti Wreda Wening Wardoyo Jawa Tengah “

Atut Andica Pravita Sari, 2013, Gambaran Tingkat Kemandirian Lansia di Dusun Blimbing Desa Sukerejo Kecamatan Sukerejo Kabupaten Ponorogo, Universitas Muhammadiyah Ponorogo.

Azizah., 2011. Keperawatan Lanjut Usia. Yokyakarta :Graha Ilmu Badan Penelitian dan Pengembangan Kesehatan, 2018, Hasil Utama RISKESDAS, Kementerian Kesehatan RI
Badan Pusat Statistik Indonesia. https://www.bps.go.id/, diakses 4 Maret 2019

Badan Pusat Statistik. Kecamatan Dalam Angka. Prevalensi Jumlah Penduduk Lansia Kabupaten Bondowoso

Edward P. Sarafino, Health Psycologi, Biopsychosocial Interactions edisi ke 7, The College of New Jersey., hlm. 98

Fitriani, S. 2011. Promosi Kesehatan. Yogyakarta: Graha Ilmu

Hardywinoto \& Setyabudi, T. 2005. Panduan Gerontology: Menjaga Keseimbangan Kualitas Hidup Para lanjut Usia. Jakarta: PT Gramedia Pustaka Utama

House \& Smett. 2002. Psikologi Kesehatan, EGC, Jakarta

Irma Mustika Sari, 2009, Faktor Yang Mempengaruhi Kemandirian Fisik Pada Pasien, Jurnal Stikes 'Aisyiyah Surakarta

Jumita Rina, Dkk, 2012, Kemandirian Lansia di Wilayah Kerja Puskesmas Lampasi Kota Paya Kambuh. Fakultas Kesehatan Masyarakat Universitas Andalans, Payahkumbuh

Mustika Irma Sari, 2009, Hubungan antara karakteristikperseonal dengan Kemandirian dalam Activity Daily Living (ADL) pada lansia di Panti Wreda Darma Bhakti Pajang Surakarta, Fakultas Ilmu Kesehatan Surakarta

Nursalam, 2015.Metodologi Penelitian Ilmu Keperawatan Pendekatan Praktis Edisi 4, Jakarta: Salemba Medika 
Padila. 2013. Buku ajar keperawatan gerontik. Yogyakarta : Nuha Medika.

Psychemate.2007.lateadulthood.htt p://www.jurnalnet.com/conte n.php?nama aduan publik\&op=detailaspirasiaduan publik-id Rista

Istafauziningtyas-

Fauziningtyas, Fkp.Web.Unair.Ac.Id/Artikel_ Kesehatan_LansiaActivities_Of_Daily_Living_Adl). Html, Diakses Pada Tanggal 10 Maret 2019

Soekidjo, Notoadmodjo, 2012. Metodogi Penelitian Kesehatan, Jakarta: PT. Renika Cipta.

Sri hartatik, 2015, Pengertian dan Ciri Kemandirian, Jurnal, https://www.academia.edu/2 334554

Sri Lestari, Psikologi Keluarga: Penanaman Nilai dan Penanganan Konflik dalam Keluarga, Jakarta: Kencana Prenada Media Group, 2012, hlm. 3

Sugiyono. 2011. Metode Penelitian Kuantitatif, Kualitatif dan R\&D. Bandung: Alfabeta

Sholehah, Faridatus. 2002. Tingkat Pengetahuan ibu usia 45 tahun keatas tentang gejala menopouse di desa sepuluh Bangkalan. KTI tidak diterbitkan. Malang. UMM

Soejono, czeresna Heriawan. 2002. Belum Memadai fasilitas bagi warga usia lanjut. http://www.kompas.com/kom pas cetak/0203/25/iptek/pert.10. htm

Undang-Undang Republik Indonesia Nomor 13 Tahun
1998 Tentang Kesejahteraan Lanjut Usia. 